\title{
The Hemolysis of Red Cells from Patients with Paroxysmal Nocturnal Hemoglobinuria by Partially Purified Sub- components of the Third Complement Component *
}

\author{
Stanley Yachnin $\dagger$ \\ (From the Department of Medicine, Unizersity of Chicago, and the Argonne Cancer Research \\ Hospital, $\ddagger$ Chicago, Ill.)
}

The role of the $\mathrm{C}^{\prime 1}$ system in the hemolysis of PNHE has been emphasized recently by the demonstration in this laboratory that PNHE lysis and classical $\mathrm{C}^{\prime}$-dependent immune lysis have similar cation requirements and $\mathrm{pH}$ optima $(2,3)$. In addition, the enhancing effects of $\mathrm{C}^{\prime} 1 \mathrm{a}, \mathrm{C}^{\prime} 1$ esterase, and $\mathrm{C}^{\prime} 1$ activators upon PNHE hemolysis suggested that the early steps of C'activation ultimately leading to PNHE lysis occurred in the fluid phase rather than in apposition to the cell membrane (4). Implicit in the latter speculation was the concept that late-acting $\mathrm{C}^{\prime}$ components were capable of direct attack upon PNHE.

* Submitted for publication January 11, 1965 ; accepted June 1, 1965.

Supported in part by the Joseph and Helen Regenstein Foundation.

Presented in part at the Fifty-seventh Annual Meeting of the American Society for Clinical Investigation, May 3, 1965, Atlantic City, N. J.

$\dagger$ John and Mary R. Markle Scholar in Academic Medicine.

Address requests for reprints to Dr. Stanley Yachnin, Dept. of Medicine, University of Chicago, 950 East 59th Street, Chicago, Ill. 60637.

$\ddagger$ Operated by the University of Chicago for the U. S. Atomic Energy Commission.

1 The following abbreviations are used: $C^{\prime}$, complement; $\mathrm{C}^{\prime} 1, \mathrm{C}^{\prime} 2, \mathrm{C}^{\prime} 3, \mathrm{C}^{\prime} 4$, the first, second, third, or fourth component of complement; R1, R2, R3, R4, RP, serum lacking the designated complement component, or properdin; $\mathrm{C}^{\prime} 1 \mathrm{a}, \mathrm{C}^{\prime} 2 \mathrm{a}$, activated first or second complement components; $C^{\prime} 1 \mathrm{q}, \mathrm{C}^{\prime} 1 \mathrm{r}, \mathrm{C}^{\prime} 1 \mathrm{~s}$, subcomponents of the first component of complement; E, erythrocytes ; A, antibody or amboceptor; EA, sensitized erythrocytes (usually sheep red cells); $\mathrm{EAC}^{\prime} \ldots$.., sensitized erythrocytes bearing complement components as designated by subscript; $\mathrm{PNH}$, paroxysmal nocturnal hemoglobinuria; PNHE, red cells from patients with paroxysmal nocturnal hemoglobinuria; NHE, normal human red cells; hu, human; gp, guinea pig ; EDTA, ethylenediamine tetraacetate. The subcomponents of human $C^{\prime} 3$ are designated by the notation $C^{\prime} 3 a, C^{\prime} 3 b, C^{\prime} 3 c$ (1).
The present report demonstrates that PNHE can be hemolyzed directly by partially purified subcomponents of the $\mathrm{C}^{\prime} 3$ complex. Central to this thesis is the observation that $\mathrm{PNHE}$ exposed to $C^{\prime} 3 a$ are converted to an intermediate complex (designated $\mathrm{PNHEC}_{3 \mathrm{a}}$ ), which is susceptible to hemolysis by dilute human serum in the presence of $\mathrm{Na}_{3} \mathrm{HEDTA}$. In addition, the serum $\mathrm{C}^{\prime}$ components involved in the hemolysis of $\mathrm{PNHEC}_{3 \mathrm{a}}^{\prime}$ are found to be identical with those involved in the lysis of $\mathrm{EAC}_{1,4,2,3 \mathrm{a}}$.

\section{Methods}

The following have all been described previously: the preparation of barbital-buffered saline (BBS) at various pH's (3) ; the preparation of $\mathrm{Na}_{2} \mathrm{MgEDTA}-\mathrm{BBS}$ containing 1.5 or $2.6 \times 10^{-2} \mathrm{M} \mathrm{Na} \mathrm{MgEDTA}_{2}(3,5)$; the collection of guinea pig and human blood and the isolation and storage of their respective sera $(3,4)$; the preparation and storage of sera deficient in the various components of $\mathrm{C}^{\prime}$ and RP (4) ; the preparation of sensitized sheep red cells both with and without the use of $\mathrm{Na}_{3} \mathrm{HEDTA}-\mathrm{BBS}(3)$; the preparation of $\mathrm{EAhuC}_{1,4,2}^{\prime}$ and $\mathrm{EAgpC}_{1,4,2}^{\prime}(3)$; the collection and storage of $\mathrm{NHE}$ and PNHE (4); the adjustment of serum $\mathrm{pH}$ (4); the preparation of serum containing EDTA salts (4); the estimation of in vitro acid hemolysis (4); the assay for C'1 esterase activity (4).

\section{Preparation of $C^{\prime} 3 a$ by TEAE chromatography}

$\mathrm{C}_{3 \mathrm{a}}^{\prime}$ was prepared as outlined by Müller-Eberhard, Nilsson, and Aronsson (6). C'3a obtained by the initial chromatographic isolation was useful in preparing $\mathrm{PNHEC}_{\mathbf{3 a}}^{\prime}$ and was so employed, but most of the experiments were performed with $\mathrm{C}^{\prime} 3 \mathrm{a}$ that had been further purified by rechromatography. After rechromatography, the fractions containing $\mathrm{C}^{\prime} 3 \mathrm{a}$ were pooled and dialyzed against 0.02 ionic strength phosphate buffer, $\mathrm{pH} 5.4$, and the precipitate was redissolved in 5 to $10 \mathrm{ml}$ of phosphatebuffered ( $\mathrm{pH} 7.0)$ isotonic saline. These fractions deteriorated slowly, and by the end of 6 to 8 weeks their activity had often disappeared. The activity could be pre- 
served by storing the fractions at $-20^{\circ} \mathrm{C}$ in $50 \%$ glycerol and dialyzing them against $0.15 \mathrm{M} \mathrm{NaCl}$ before use.

\section{Formation of the PNHEC'sa complex}

Nine different batches of $C^{\prime} 3 a$ were prepared, of which six were rechromatographed; no $C^{\prime} 1$ esterase activity was detectable in any of these preparations. All were effective in converting $\mathrm{PNHE}$ to $\mathrm{PNHEC}_{3 \mathrm{a}}$. After both reactants had been prewarmed to $37^{\circ} \mathrm{C}$, a portion of $\mathrm{C}^{\prime} 3 \mathrm{a}$ was added to a cell button of PNHE, and the mixture was incubated at $37^{\circ}$ for 5 minutes. Volumes of PNHE ranged from 0.01 to $0.5 \mathrm{ml}$, and volumes of $C^{\prime} 3 a$ ranged from 0.1 to $2 \mathrm{ml}$. The mixture was then placed on ice and washed twice $\left(2^{\circ} \mathrm{C}\right)$ with $10 \mathrm{ml} 0.15 \mathrm{M} \mathrm{NaCl}$. In certain experiments $1 \mathrm{ml}$ of human serum, $\mathrm{pH} 6.5$, containing $0.015 \mathrm{M} \mathrm{Na}{ }_{3} \mathrm{HEDTA}$ was added directly to the $\mathrm{PNHEC}_{3 \mathrm{a}}^{\prime}$ cell button, and hemolysis was carried out at $37^{\circ}$ for 30 minutes. In those experiments where the $\mathrm{PNHEC}_{3 \mathrm{a}}^{\prime}$ complex was prepared in bulk, the washed cells were suspended to a concentration of 20 to $40 \%$, and $0.05 \mathrm{ml}$ was added to tubes containing $1-\mathrm{ml}$ portions of the $\mathrm{Na}_{3} \mathrm{HEDTA}$ human serum or other reagents. The dose of $\mathrm{PNHEC}_{3 \mathrm{a}}$ employed in each hemolytic test ranged from an equivalent of 0.01 to $0.02 \mathrm{ml}$ packed cells, and the $100 \%$ hemolysis, OD $540 \mathrm{~m} \mu$ (determined by freeze and thaw), ranged from 1.5 to 4.0 .

\section{Isolation of the serum factors involved in PNHEC'sa hemolysis}

Four hundred fifty to $600 \mathrm{ml}$ of human serum was mixed with one-tenth vol of $0.1 \mathrm{M} \mathrm{Na}{ }_{3} H E D T A, p H ~ 7.4$, and dialyzed against $12 \mathrm{~L} 0.02$ ionic strength acetate buffer, $\mathrm{pH} 5.4$, containing $10^{-3} \mathrm{M} \mathrm{Na} \mathrm{NaDT}_{3} \mathrm{HED}$ for 16 to 24 hours. The euglobulin precipitate was collected by centrifugation, washed twice in dialysis buffer, and dissolved in $25 \mathrm{ml}$ phosphate buffer, ionic strength $0.15, \mathrm{pH} 7.4$, containing $1 \% \mathrm{NaCl}$ and $10^{-8} \mathrm{M} \mathrm{Na} \mathrm{Na}_{3} \mathrm{HEDTA}$. After removal of insoluble material and lipid by low and high speed centrifugation (6), the protein solution was dialyzed overnight against starting buffer. Starting buffer was either 0.15 ionic strength phosphate, $\mathrm{pH} 7.4$ (2 experiments), or 0.09 ionic strength phosphate buffer, $\mathrm{pH}$ 7.4 (2 experiments), both containing $10^{-3} \mathrm{M} \mathrm{Na}$ HEDTA. No significant differences were noted when the elution patterns for these two buffers were compared. The dialyzed protein solution was cleared of any precipitate by low speed centrifugation and placed on a $2-\times 40-\mathrm{cm}$ column of DEAE resin previously equilibrated with starting buffer. The columns were developed with a linear ionic strength gradient (starting buffer as described; limit buffer, $0.5 \mathrm{M} \mathrm{NaCl}$ in starting buffer). In three experiments, $1,000 \mathrm{ml}$ of each buffer was employed for gradient development. In a single experiment, in order to avoid trace contamination of the $\mathrm{C}^{\prime} 3$ subcomponents by each other, $2,000 \mathrm{ml}$ of each buffer was employed. Twenty-ml fractions were collected at a flow rate of 15 to $30 \mathrm{ml}$ per hour. The individual fractions were dialyzed overnight against $0.135 \mathrm{M} \mathrm{NaCl}$ containing $10^{-3} \mathrm{Na}_{3}$ HEDTA. The entire isolation procedure was carried out at $4^{\circ} \mathrm{C}$. After dialysis, the fractions were analyzed for
$\mathrm{C}^{\prime} 1 \mathrm{q}, \mathrm{C}^{\prime} 1 \mathrm{r}$, and $\mathrm{C}^{\prime} 1 \mathrm{~s}$ activities (5), for $\mathrm{C}^{\prime} 3 \mathrm{a}$ activity (5, 7 ), for lytic activity against $\mathrm{PNHEC}_{3 \mathbf{3}}$, and for hemolytic activity against $\mathrm{EAC}_{\mathbf{1 , 4 , 2 , 3 2}}^{\prime}$. Comparable results were obtained in all four experiments. Activities isolated by this technique were stored at $-85^{\circ} \mathrm{C}$.

\section{Methods of assay}

$C^{\prime} 1 q, C^{\prime} 1 r, C^{\prime} 1 s$. The procedure was similar to that outlined by Lepow and his associates (5).

$C^{\prime} 3 a$. This activity was usually measured . with $\mathrm{EAgpC}_{1,4,2}^{\prime} \quad$ A sample of the fraction to be tested was added to a $5 \times 10^{8}$ cell button of $\mathrm{EAgpC}_{1,4,2}$ together with $4 \mathrm{ml}$ of a $1: 5,000$ dilution of guinea pig $\mathrm{C}^{\prime}$ in $\mathrm{Na}_{3} \mathrm{HEDTA}-\mathrm{BBS}, \mathrm{pH} 7.4$ (5). Hemolysis was carried out at $37^{\circ}$ for 60 minutes. Appropriate blanks and controls were included. The activity of $C^{\prime} 3 \mathrm{a}$ was also measured with $\mathrm{EAhuC}_{1,4,2}^{\prime}$ with a $1: 800$ or $1: 1,000$ dilution of human serum in $\mathrm{Na}_{3} \mathrm{HEDTA}-\mathrm{BBS}$. Similar results were obtained.

Serum factors involved in PNHEC'sa hemolysis. All tests for the ability of DEAE chromatography fractions to hemolyze $\mathrm{PNHEC}_{3 \mathrm{a}}^{\prime}$ were carried out in the presence of $7.5 \times 10^{-3} \mathrm{M} \mathrm{Na}{ }_{3} \mathrm{HEDTA}$ with $\mathrm{Na}_{3} \mathrm{HEDTA}-\mathrm{BBS}, \mathrm{pH}$ 6.5 , as diluent where indicated. Assays for these activities were carried out as follows: $0.1 \mathrm{ml}$ of the fraction to be tested was added to $1 \mathrm{ml} \mathrm{Na}$ HEDTA-BBS, $\mathrm{pH} 6.5$, together with $0.1 \mathrm{ml}$ of a fraction of known activity and $0.05 \mathrm{ml}$ of a $20 \%$ suspension of $\mathrm{PNHEC}_{3 \mathrm{a}}$. Hemolysis was carried out by incubating the mixture at $37^{\circ}$ for 30 minutes. Appropriate controls employing one of the test fractions with $\mathrm{PNHEC}_{\mathbf{3 a}}$, and both test fractions with PNHE, were included.

Serum factors involved in the lysis of $E A C^{\prime}{ }_{1,4,2,3 a}$. These assays were carried out with $\mathrm{EAC}^{\prime}{ }_{1,4,2}$ and $\mathrm{C}^{\prime} 3 \mathrm{a}$; identical results were obtained with $\operatorname{EAgpC}_{1,4,2}^{\prime}$ and EAhuC ${ }_{1,4,2}$. Hemolysis could be produced by a combination of $\mathrm{EAC}_{1,4,2}^{\prime}, \mathrm{C}^{\prime} 3 \mathrm{a}$, an early $\mathrm{DEAE}$ fraction $\left(C^{\prime} 3 b\right)$, and a late DEAE fraction $\left(C^{\prime} 3 c\right)$ (1). The assays were carried out as follows: The fractions to be tested were diluted $1: 25$ or $1: 50$ in $\mathrm{Na}_{3} \mathrm{HEDTA}-\mathrm{BBS}$, $\mathrm{pH}$ 7.4. A $5 \times 10^{8}$ button of $\mathrm{EAC}_{1,4,2}^{\prime}$ at $0^{\circ} \mathrm{C}$ was combined with a sample of $\mathrm{C}^{\prime} 3 \mathrm{a}, 2 \mathrm{ml}$ of a dilution of known activity, and $2 \mathrm{ml}$ of a dilution of the fraction to be tested. The cell suspension was then incubated at $37^{\circ}$ for $60 \mathrm{~min}$ utes. Appropriate controls (with and without $C^{\prime} 3 a$ ) and blanks were always included.

\section{Other procedures}

Immunoelectrophoresis was performed on rechromatographed $C^{\prime} 3 a$ preparations. The antisera employed were a rabbit antihuman serum, ${ }^{2}$ rabbit antihuman gamma globulin serum, ${ }^{2}$ and rabbit antihuman $\beta_{\mathrm{Ic}}$-globulin serum. The latter was prepared from an antihuman $C^{\prime}$ serum $^{3}$

2 Prepared by Behringwerke Ag. and distributed in the United States by Lloyd Bros., Cincinnati, Ohio.

3 Prepared by the Central Laboratory of the Netherlands Red Cross Blood Transfusion Service, Amsterdam, Holland, and kindly supplied by Dr. Fred Rosen, Children's Medical Center, Boston, Mass. 
containing antibodies to both $\beta_{1 \mathrm{e}}$-globulin and $\beta_{\mathrm{Ic}}$-globulin by absorption with human red cells coated with incomplete cold antibody (8).

Coombs tests were performed on both PNHE and NHE with and without exposure to $C^{\prime} 3 a$. Two-hundredths $\mathrm{ml}$ of PNHE or NHE was exposed to $0.3 \mathrm{ml}$ saline or $C^{\prime} 3$ a containing $5,000 \mu \mathrm{g}$ protein per $\mathrm{ml}$ for 5 minutes at $37^{\circ}$. They were then washed four times with $10 \mathrm{ml}$ saline at $2^{\circ} \mathrm{C}$ and suspended to a $3 \%$ cell concentration. One drop of each cell suspension was added to 2 drops of antiserum dilution in $10-\times 75-\mathrm{cm}$ test tubes. After incubation at $37^{\circ}$ for 30 minutes with frequent agitation, the cell suspensions were allowed to stand at room temperature for 60 minutes, and the hemagglutination pattern was noted. A smooth carpet of cells was taken as a $4+$ pattern and a dense central button as a negative pattern. All antisera were heated at $56^{\circ}$ for 30 minutes and absorbed three times at $0^{\circ}$ with one-half vol of washed human red cells before use. In certain experiments antiserum was absorbed with $\mathrm{C}^{\prime} 3 \mathrm{a}$ before use; 1 vol of anti- serum, 1 vol of $\mathrm{C}^{\prime} 3 \mathrm{a}(5,000 \mu \mathrm{g}$ protein per $\mathrm{ml})$, and 8 vol of saline were mixed and incubated at $37^{\circ}$ for 30 minutes.

Preparation of the TEAE 4 and DEAE 5 resins for column chromatography was as described by Müller-Eberhard and his colleagues (6) and by Lepow and his associates (5). Conductivity measurements were made with a conductivity bridge. ${ }^{6} \mathrm{pH}$ measurements were

${ }^{4}$ Two different TEAE resins were employed with comparable results : 1) Cellex-T, Biorad Laboratories, Richmond, Calif., lot no. B-1548, capacity $0.76 \mathrm{mEq}$ per g. 2) Gallard-Schlesinger Chemical Mfg. Corp., Garden City, N. Y., lot no. A 3849 , capacity $0.73 \mathrm{mEq}$ per g.

5 Two different DEAE resins were employed with comparable results: 1) Selectacel, Schleicher and Schuell, Keene, N. H., capacity $0.95 \mathrm{mEq}$ per g. 2) GallardSchlesinger Chemical Mfg. Corp., Garden City, N. Y., lot no. A 4769 , capacity $1.18 \mathrm{mEq}$ per $\mathrm{g}$.

${ }^{6}$ Model RC16B2, Industrial Instruments, Cedar Grove, N. J.

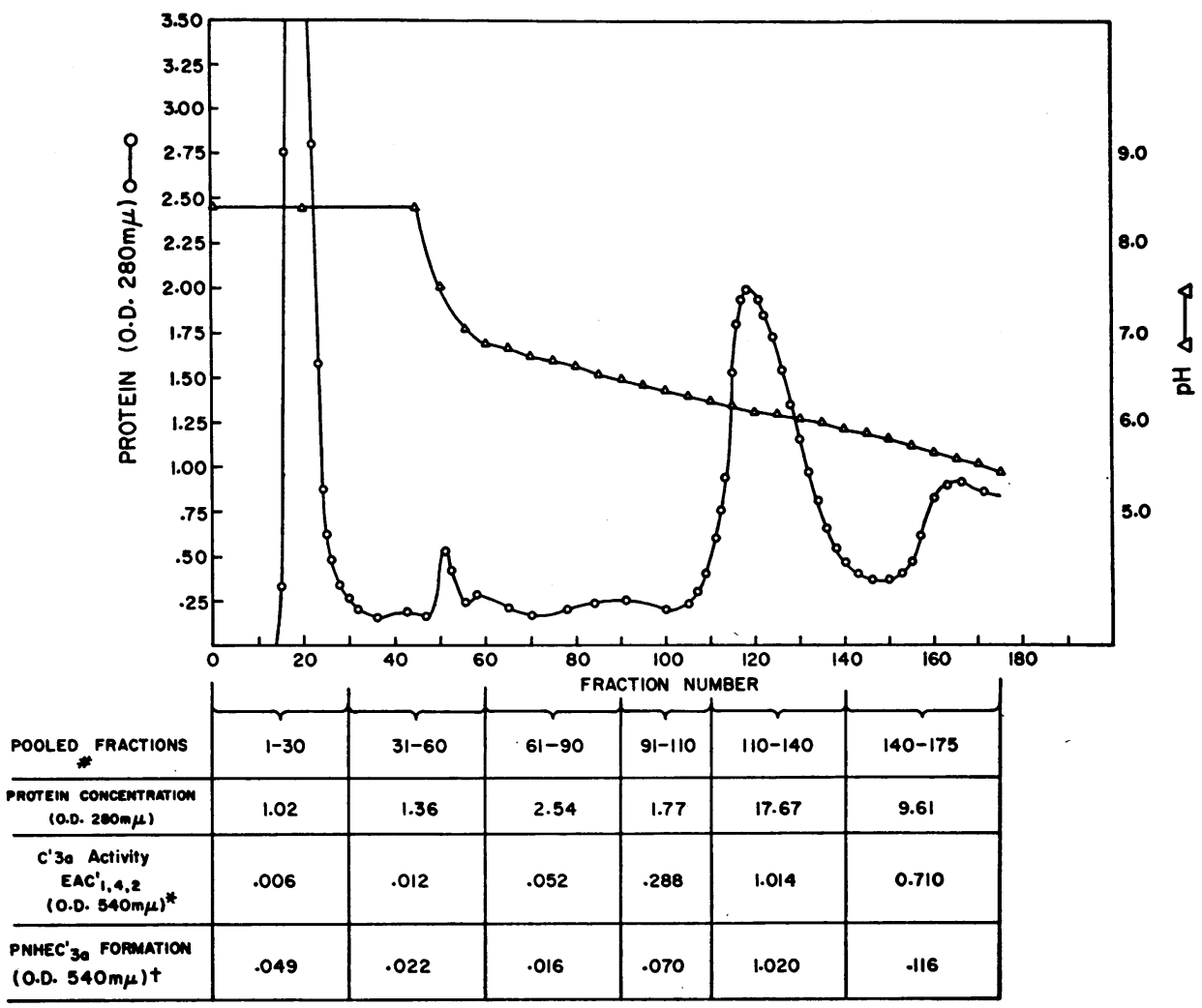

* $100 \%$ LYSIS $=0.0 .1 .290$

$+100 \%$ LYSIS $=0.0 .1 .70$

Fig. 1. The isolation of C'3a by TEAE chromatography. The bracketed fractions were pooled, and the protein was reprecipitated and dissolved in a small volume of phosphate-buffered saline. The pooled fractions were tested for $\mathrm{C}^{\prime} 3 \mathrm{a}$ activity with $\mathrm{EAC}_{1,4,2}{ }^{2}$ and PNHE. See text, footnote 1, for abbreviations in all figures; $\mathrm{PNHEC}_{3 \mathrm{a}}$ designates an intermediate complex produced by exposure of PNHE to $C^{\prime} 3 a$. 


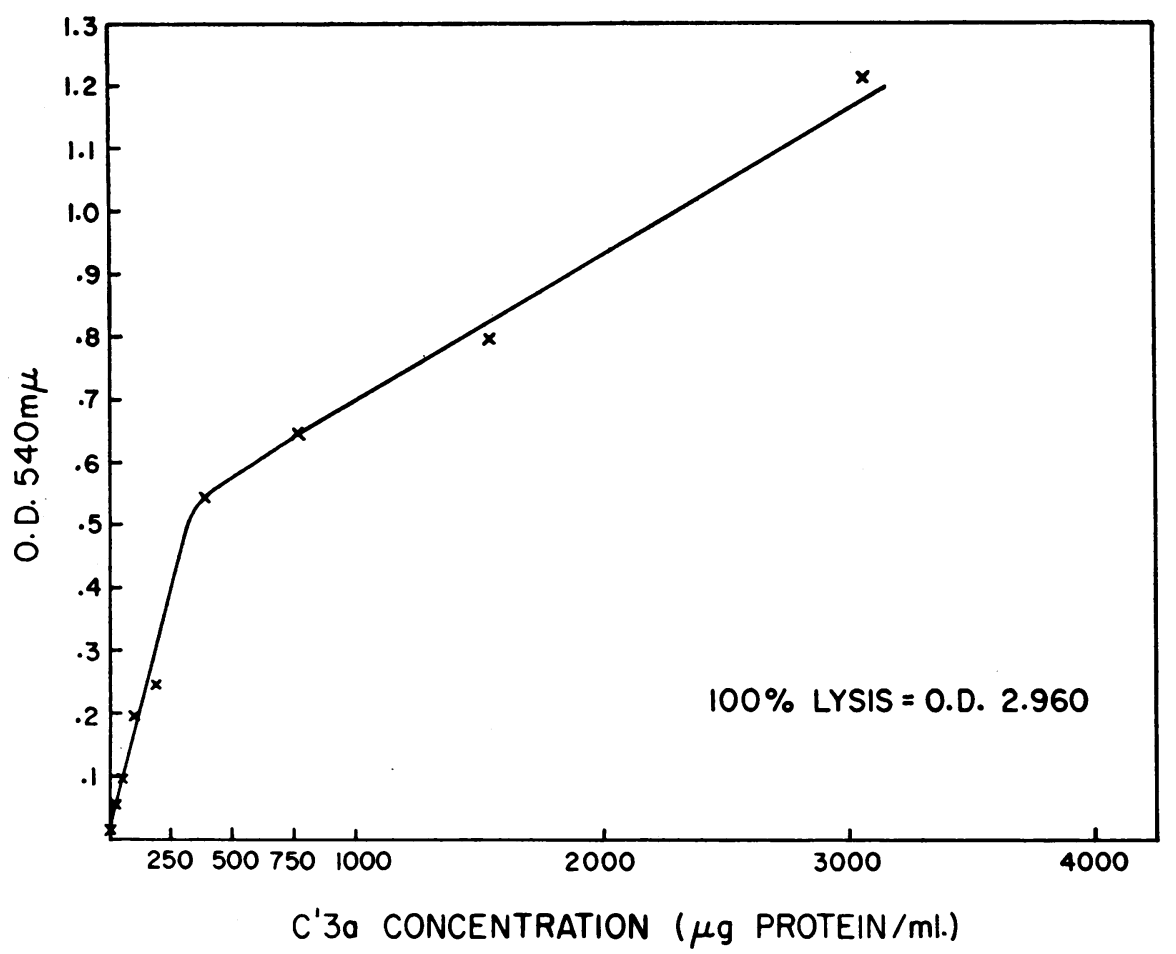

Fig. 2. The effect of C'3a Protein concentration on PNHEC'sa formation. Twohundredths $\mathrm{ml}$ PNHE was mixed with $0.5 \mathrm{ml} \mathrm{C} 3 \mathrm{a}$ at various protein concentrations. After 5 minutes incubation at $37^{\circ} \mathrm{C}$, the cells were washed, and $1 \mathrm{ml}$ of a $1: 25$ dilution of human serum in $\mathrm{Na}_{3} \mathrm{HEDTA}-\mathrm{BBS}$ (barbital-buffered saline), $\mathrm{pH} 6.5$, was added to the cell button.

made with a Beckman Zeromatic pH meter. A Zeiss PMQ II spectrophotometer and cuvettes with a $1-\mathrm{cm}$ light path were employed in all measurements of optical density. Protein determinations were made by a modified Folin technique (9) with human gamma globulin as the standard. The absorbancy at $280 \mathrm{~m} \mu$ of a $1 \%$ protein solution of partially purified $\mathrm{C}^{\prime} 3 \mathrm{a}$ was 12 .

All the experiments reported were performed on more than one occasion, with different cells and different reagent preparations, and the results were always reproducible.

\section{Results}

Figure 1 shows the relationship between $C^{\prime} 3 a$ activity, as measured by $\mathrm{EAC}_{1,4,2}^{\prime}$ lysis in a 1:5,000 dilution of guinea pig serum, and the material isolated by TEAE chromatography that was capable of transforming $\mathrm{PNHE}$ to $\mathrm{PNHEC}_{3 \mathbf{a}}$. Only the fraction pools containing $\mathrm{C}^{\prime} 3$ a activity as measured by $\mathrm{EAC}_{1,4,2}^{\prime}$ were capable of $\mathrm{PNHEC}_{3 \mathrm{a}}$ formation. On one occasion the peak fractions containing $\mathrm{C}^{\prime} 3 \mathrm{a}$ activity from the initial chromatographic separation were dialyzed against $0.15 \mathrm{M}$ $\mathrm{NaCl}$ and used directly in an attempt to convert
PNHE to $\mathrm{PNHEC}_{3 \mathrm{a}}^{\prime}$. This attempt was unsuccessful.

PNHEC $_{\text {sa }}$ formation. Twenty-five to $50 \mu \mathrm{g}$ $\mathrm{C}^{\prime} 3 \mathrm{a}$ protein per $\mathrm{ml}$ effects a barely discernible conversion of $\mathrm{PNHE}$ to $\mathrm{PNHEC}_{3 \mathbf{a}}$ (Figure 2). With concentrations of $\mathrm{C}^{\prime} 3 \mathrm{a}$ above $500 \mu \mathrm{g}$ protein per $\mathrm{ml}$ the slope of $\mathrm{PNHEC}_{\mathbf{3 a}}^{\prime}$ formation diminishes.

Experiments to determine the cation requirements for formation of $\mathrm{PNHEC}_{3 \mathrm{a}}^{\prime}$ revealed that the intermediate complex was formed equally well in the presence of $\mathrm{Na}_{2} \mathrm{MgEDTA}$ and $\mathrm{Na}_{3} \mathrm{HEDTA}$ as in the presence of $\mathrm{Ca}^{++}$and $\mathrm{Mg}^{++}$. It was concluded, therefore, that neither of these divalent cations was necessary for $\mathrm{PNHEC}_{3 \mathbf{a}}$ formation, and that fluid phase $\mathrm{C}^{\prime} 1$ or $\mathrm{C}^{\prime} 2$, should they be present as contaminants in our $C^{\prime} 3$ a preparation, were not participating in the conversion (10). However, the possibility that a cell bound complement component was playing a role in $\mathrm{C}^{\prime} 3 \mathrm{a}$ attachment was not excluded. Accordingly, $\mathrm{PNHE}$ were decayed at $37^{\circ}$ for 2 hours in BBS or in $\mathrm{Na}_{3-}$ 


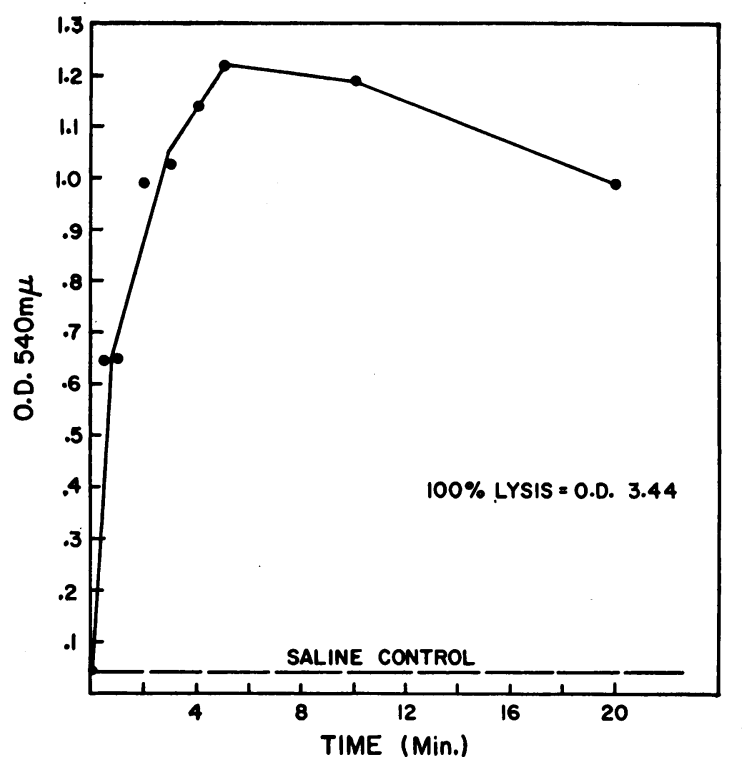

Fig. 3. The kinetics of PNHEC' ${ }_{3 a}$ formation. Two-tenths $\mathrm{ml}$ PNHE was mixed with $5 \mathrm{ml}$ of $\mathrm{C}^{\prime} 3 \mathrm{a}$ ( 500 $\mu \mathrm{g}$ protein per $\mathrm{ml}$ ) at $37^{\circ}$. At the designated time intervals $0.5-\mathrm{ml}$ samples were removed and added to cold $0.15 \mathrm{M} \mathrm{NaCl}$. After washing, the cell buttons were hemolyzed in $1 \mathrm{ml}$ undiluted human serum, $\mathrm{pH} 6.5$, containing $0.015 \mathrm{M} \mathrm{Na} \mathrm{NaDTA}_{3} \mathrm{HED}$.

HEDTA-BBS and subsequently were tested for their ability to form $\mathrm{PNHEC}_{3 \mathrm{a}}^{\prime}$. The results revealed that such decay did not affect the subsequent formation of $\mathrm{PNHEC}_{3 \mathrm{a}}$ and eliminated the possibility that $C^{\prime} 1$ or $C^{\prime} 2$ need be on the cell for PNHEC $_{3 \mathrm{a}}^{\prime}$ formation to occur $(11,12)$.

$\mathrm{PNHEC}_{\mathbf{3}}^{\prime}$ formation was completely inhibited by low temperature $\left(0^{\circ} \mathrm{C}\right)$. Furthermore, preheating $\mathrm{C}^{\prime} 3 \mathrm{a}$ at $56^{\circ} \mathrm{C}$ for 30 minutes completely destroyed its ability to effect $\mathrm{PNHEC}_{3 \mathrm{a}}^{\prime}$ formation. During exposure of $\mathrm{C}^{\prime} 3 \mathrm{a}$ to $56^{\circ}$ much of the protein formed a white precipitate. PNHEC $_{3 \mathbf{a}}$ formation proceeded equally well at $\mathrm{pH} 6.5,7.0$, and 7.5 ; slight inhibition was noted at $\mathrm{pH}$ 6.0.

The kinetics of $\mathrm{PNHEC}_{3 \mathbf{a}}$ formation superficially resembled those of the formation of $\operatorname{EAC}_{1,4,2}^{\prime}(10 a, 13)$. The complex formed rapidly, reached an optimum at approximately 5 minutes of PNHE exposure to $\mathrm{C}^{\prime} 3 \mathrm{a}$, and then began to decline in activity (Figure 3 ). The decay of PNHEC $_{3 a}^{\prime}$ could be impeded by low temperature (Figure 4). The rate of decay at $37^{\circ}$ was much slower than that associated with $\mathrm{EAC}^{\prime}{ }_{1,4,2}$ and did not follow first order kinetics. In addition, PNHEC $_{3 \text { A }}^{\prime}$ maintained at $37^{\circ}$ in the presence of a large excess of $\mathrm{C}^{\prime} 3 \mathrm{a}$ were able to escape decay. The optimal time of exposure of PNHE to $\mathrm{C}^{\prime} 3 \mathrm{a}$ for $\mathrm{PNHEC}_{3 \mathrm{a}}^{\prime}$ formation varied with the concentration of $\mathrm{C}^{\prime} 3 \mathrm{a}$ and also differed slightly with various batches of $\mathrm{C}^{\prime} 3 \mathrm{a}$; however, a 5-minute exposure of $\mathrm{PNHE}$ to $\mathrm{C}^{\prime} 3 \mathrm{a}$ at $37^{\circ}$ yielded satisfactory results in all instances. No hemolysis of PNHE occurred during prolonged exposure to $\mathrm{C}^{\prime} 3 \mathrm{a}$ or during subsequent decay at $37^{\circ}$; thus $\mathrm{C}^{\prime} 3 \mathrm{a}$ was unable, by itself, to produce PNHE lysis.

Various studies on the lysis of PNHEC' ${ }_{s a}$. The $\mathrm{PNHEC}_{3 \mathrm{a}}{ }$ complex is identifiable by its ability to hemolyze in the presence of $\mathrm{Na}_{3} \mathrm{HEDTA}$. Red cells from ten patients with $\mathrm{PNH}$ were studied during the course of these experiments; none were capable of significant hemolysis in human serum containing $\mathrm{Na}_{3} \mathrm{HEDTA}$. All were capable of conversion to the intermediate complex $\mathrm{PNHEC}_{3 \mathrm{a}}$, as measured by susceptibility to hemolysis in the same reagent. Study of the optimal $\mathrm{pH}$ for hemolysis of $\mathrm{PNHEC}_{3 \mathrm{a}}^{\prime}$ in $\mathrm{Na}_{3} \mathrm{HEDTA}$ human serum revealed that hemolysis could proceed over an expanded $\mathrm{pH}$ range, a broad optimum for hemolysis occurring between $\mathrm{pH} 6.5$ and 6.0 (3 experiments).

The native $\mathrm{PNH}$ cell loses its capacity to undergo hemolysis in very low dilutions of serum and is usually resistant to hemolysis in serum dilutions of $1: 4$ or higher (2). In marked contrast, the

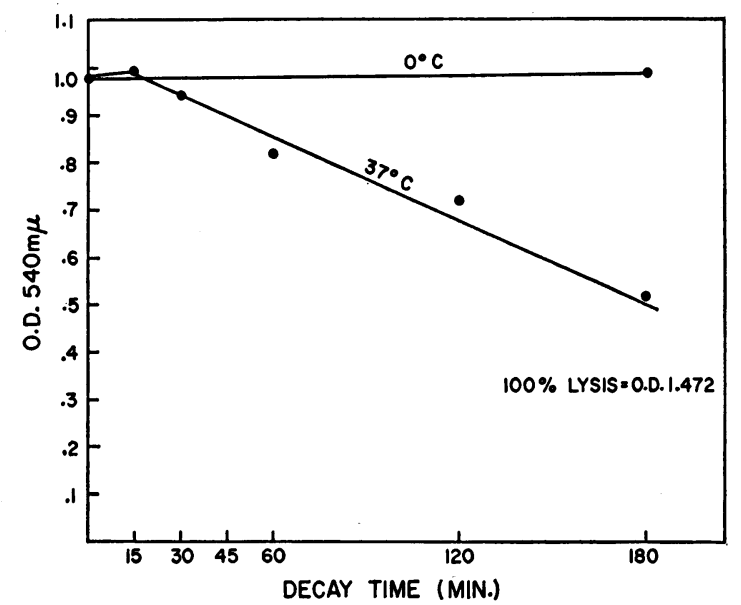

Fig. 4. THE EFFECT OF TEMPERAtURE UPON THE DECAY of $\mathrm{PNHEC}_{3 \mathrm{a}}$. A $20 \%$ suspension of $\mathrm{PNHEC}_{3 \mathrm{a}}$ was maintained at the designated temperatures; $0.05-\mathrm{ml}$ samples were removed at intervals and tested for hemolysis in $1 \mathrm{ml}$ of a $1: 16$ dilution of human serum in $\mathrm{Na}_{3} \mathrm{HEDTA}$ BBS pH 6.5. 


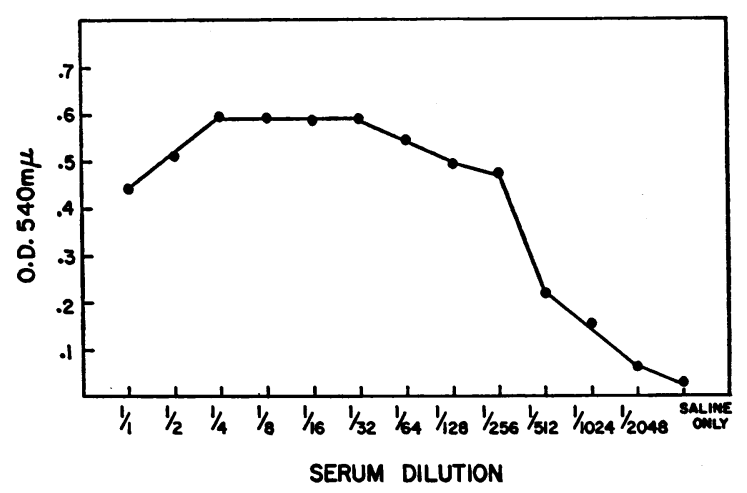

Fig. 5. The ABIlity of PNHEC' ${ }_{3 a}$ to Hemolyze in VARIOUS DILUTIONS OF HUMAN SERUM. Samples of a single PNHEC $_{3 \mathbf{s}}$ preparation were added to $1 \mathrm{ml}$ of serial twofold dilutions of human serum in $\mathrm{Na}_{3} \mathrm{HEDTA}-\mathrm{BBS}$, $\mathrm{pH}$ 6.5. The undiluted serum contained $0.015 \mathrm{M}$ $\mathrm{Na}_{3} \mathrm{HEDTA}$.

PNHEC $_{3 \mathbf{a}}$ complex was susceptible to hemolysis by extremely high dilutions of human serum in $\mathrm{Na}_{3} \mathrm{HEDTA}-\mathrm{BBS}$; substantial hemolysis of PNHEC $_{3 \mathbf{a}}^{\prime}$ occurred in dilutions of human serum as high as $1: 1,024$ (Figure 5). Peak hemolysis was usually observed between serum dilutions of $1: 4$ and $1: 32$. After these observations most tests for $\mathrm{PNHEC}_{3 \mathrm{a}}^{\prime}$ hemolysis utilizing whole serum were performed in a $1: 16$ or $1: 25$ dilution of serum in $\mathrm{Na}_{3} \mathrm{HEDTA}-\mathrm{BBS}, \mathrm{pH} 6.5$.

The hemolysis of PNHE in whole human serum is dependent upon the presence of all four major $\mathrm{C}^{\prime}$ components as well as properdin (4). The experiment shown in Figure 6 was done to determine the major $\mathrm{C}^{\prime}$ components that were necessary to

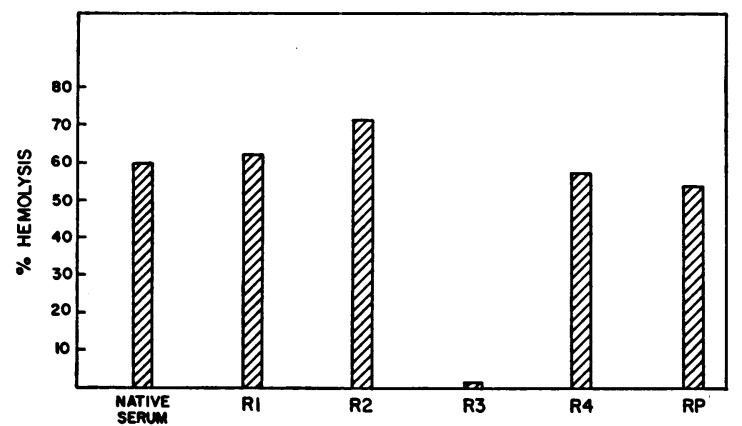

Fig. 6. The ability of various R REAGENTS to SUPPORT THE HEMOLYSIS OF PNHEC ${ }_{3 \mathrm{a}}$ All hemolytic tests were carried out in $1-\mathrm{ml}$ portions of the indicated reagent containing $0.1 \mathrm{ml} 0.15 \mathrm{M} \mathrm{Na} \mathrm{H}_{3} \mathrm{HETA}$ at $\mathrm{pH}$ 6.5. PNHE will not hemolyze in serum containing $\mathrm{Na}_{s} \mathrm{HEDTA}$ or in any $R$ reagent containing $\mathrm{Na}_{3} \mathrm{HEDTA}$ (not shown).

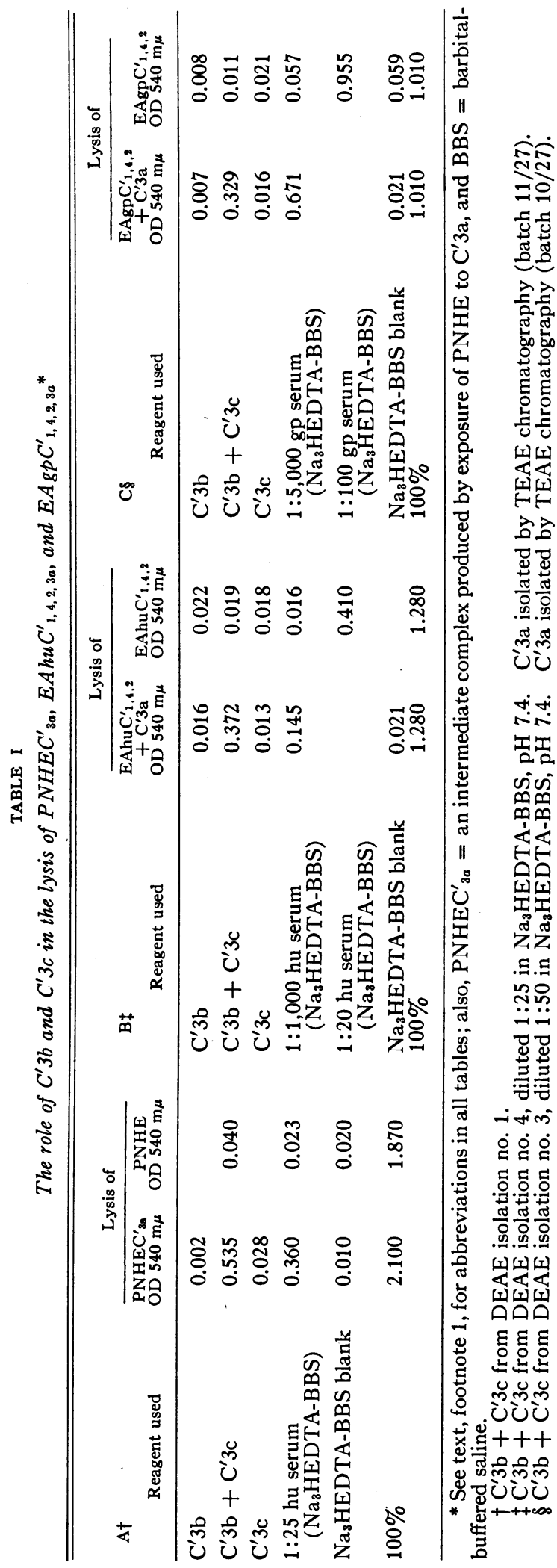




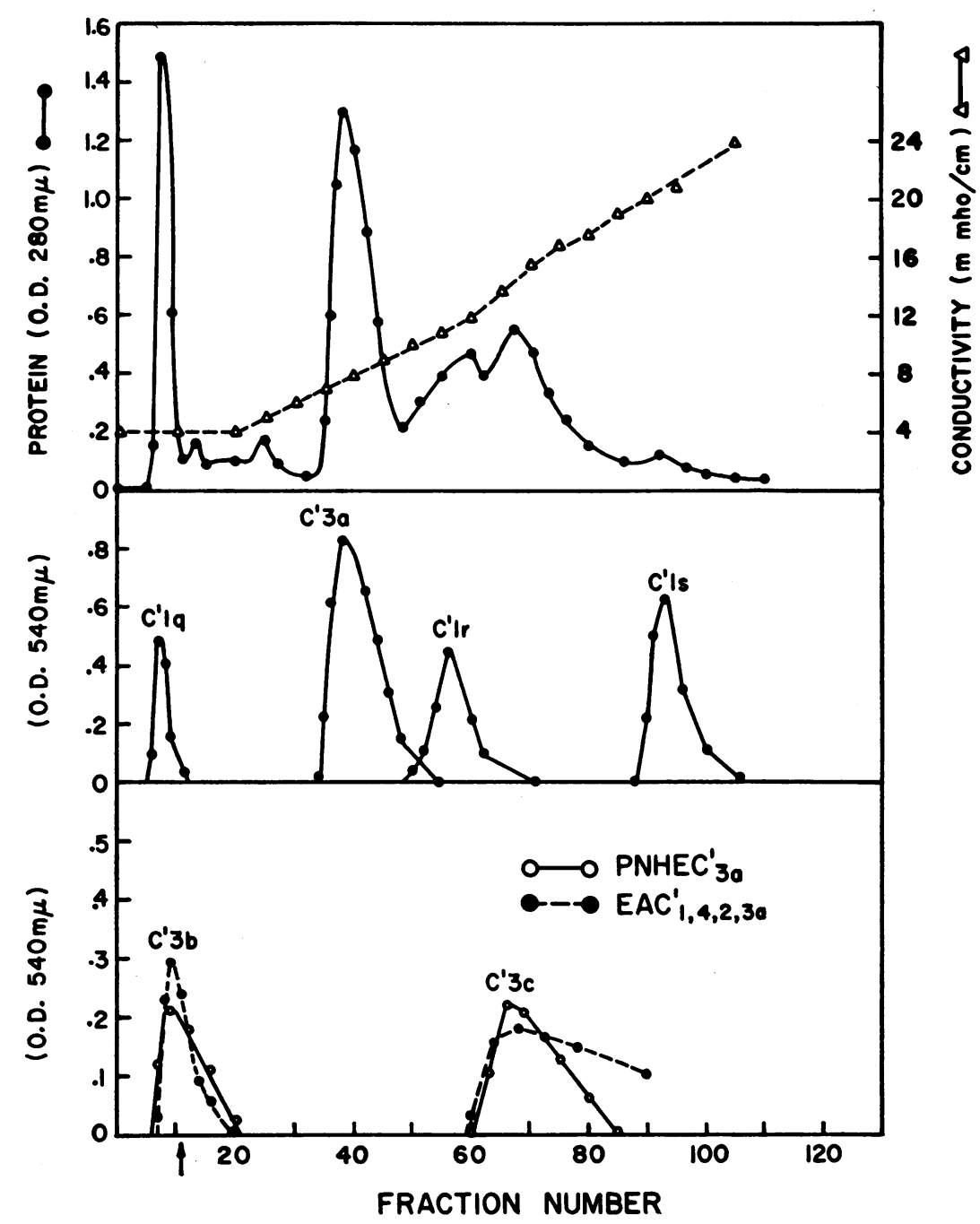

Fig. 7. Isolation of the serum factors ( $C^{\prime} 3 b, C^{\prime} 3 c$ ) involved in PNHEC' $_{3 a}$ HEMOLYSIS BY DEAE ChRomatography. The arrow indicates the start of the $\mathrm{NaCl}$ gradient. Starting buffer, 0.09 ionic strength phosphate, $\mathrm{pH} 7.4 ; 2,000 \mathrm{ml}$ each starting and limit buffers were employed for gradient development.

support the hemolysis of $\mathrm{PNHEC}_{3 \mathrm{a}}$. Serum heated at $56^{\circ} \mathrm{C}$ for 30 minutes would no longer hemolyze $\mathrm{PNHEC}_{3 \mathrm{aa}}$. $\mathrm{PNHEC}_{3 \mathrm{a}}$ were no more susceptible to acid hemolysis in native human serum than PNHE. Hemolysis of $\mathrm{PNHEC}_{3 \mathrm{a}}$ proceeded satisfactorily in R1, R2, R4, and RP. The only $\mathrm{R}$ reagent totally and consistently lacking in the ability to hemolyze $\mathrm{PNHEC}_{3 \mathrm{a}}^{\prime}$ was $\mathrm{R} 3$, suggesting that some part of the $\mathrm{C}^{\prime} 3$ complex was responsible for the lysis of PNHEC $^{\prime} 3 \mathrm{a}$.

Isolation of the serum factors involved in PNHEC' ${ }_{s a}$ hemolysis: their identity with $C^{\prime} 3 b$ and $C^{\prime} 3 c$. Figure 7 demonstrates the results ob- tained when the DEAE resin chromatographic fractions were analyzed for various hemolytic activities. No single fraction was capable of hemolyzing either $\mathrm{PNHEC}_{3 \mathrm{a}}^{\prime}$ or $\mathrm{EAC}_{1, \mathbf{4}, \mathbf{2}, \mathbf{a}}$; the combination of an early fraction $\left(\mathrm{C}^{\prime} 3 \mathrm{~b}\right)$ with a late fraction $\left(C^{\prime} 3 c\right)$ was effective in lysing both intermediate complexes. The pattern of elution of $\mathrm{C}^{\prime} 3 \mathrm{~b}$ and $\mathrm{C}^{\prime} 3 \mathrm{c}$ as measured by $\mathrm{PNHEC}_{3 \mathrm{a}}^{\prime}$ resembled closely that measured by use of $\mathrm{EAC}_{1,4,2,3 \mathrm{a}}^{\prime}$. Table I illustrates the need for both $\mathrm{C}^{\prime} 3 \mathrm{~b}$ and $\mathrm{C}^{\prime} 3 \mathrm{c}$ in the lysis of all the $C^{\prime} 3 \mathrm{a}$ intermediate complexes studied.

The effect of $C^{\prime} 3 a$ on normal human erythro- 
cytes. Two of the undiluted rechromatographed $C^{\prime} 3$ a preparations were effective in forming an intermediate complex $\mathrm{NHEC}_{3 \mathbf{a}}$, which is susceptible to hemolysis in dilute $\mathrm{Na}_{3} \mathrm{HEDTA}$ human serum. Table II illustrates this effect and compares the efficacy of this transformation with that effected simultaneously against PNHE. The PNHE used were approximately 40 times more susceptible to complex formation than were NHE. Another $\mathrm{C}^{\prime} 3 \mathrm{a}$ preparation was even more effective in transforming $\mathrm{NHE}$ to $\mathrm{NHEC}_{3 \mathbf{a}}^{\prime}$, but unfortunately decayed before PNHE could be obtained for parallel assay. All of the experiments cited herein concerning the formation of $\mathrm{PNHEC}_{3 \mathbf{a}}$ were done with amounts, or preparations, of $\mathrm{C}_{3 \mathrm{a}}^{\prime}$ that were ineffective in forming $\mathrm{NHEC}_{3 \mathrm{a}}^{\prime}$. Table III shows the capacity of PNHE from six patients to combine with $\mathrm{C}^{\prime} 3 \mathrm{a}$ and contrasts their capacity to do so with $\mathrm{NHE}$ and with red cells from three patients displaying substantial reticulocytosis not related to a hemolytic anemia. The ability of PNHE to react with
TABLE II

Comparison of PNHE (case Pe) and $N H E$ reaction with $C^{\prime} 3 a$

\begin{tabular}{cccccc}
\hline \hline & \multicolumn{2}{c}{ NHE } & & \multicolumn{2}{c}{ PNHE } \\
\cline { 2 - 3 } \cline { 5 - 6 } C'3a concentration & $\begin{array}{c}\text { OD } \\
540 \mathrm{~m} \mu\end{array}$ & Lysis* & & $\begin{array}{c}\text { OD } \\
540 \mathrm{~m} \mu\end{array}$ & Lysis* \\
\hline$\mu g$ protein/ml & & $\%$ & & & $\%$ \\
$5,000 \dagger$ & 0.144 & 7.8 & & 0.970 & 59.5 \\
$1,000 \ddagger$ & 0.010 & 0.5 & & 0.465 & 28.5 \\
$500 \ddagger$ & 0.002 & 0.1 & & 0.404 & 24.8 \\
$250 \ddagger$ & 0.002 & 0.1 & & 0.185 & 11.3 \\
$125 \ddagger$ & 0.000 & 0.1 & & 0.104 & 6.4 \\
Saline control & 0.004 & 0.2 & & 0.007 & 0.4 \\
$100 \%$ & 1.840 & & & 1.630 & \\
\hline
\end{tabular}

* In 1:25 hu serum, NasHEDTA-BBS, pH 6.5.

$\dagger$ Two-tenths ml $\mathrm{C}^{\prime} 3 \mathrm{a} / 0.01 \mathrm{ml}$ NHE or PNHE, $37^{\circ} \mathrm{C}, 5$ minutes.
$\ddagger$ Five-tenths $\mathrm{ml} \mathrm{C} \mathrm{C}^{\prime} 3 \mathrm{a} / 0.01 \mathrm{ml} \mathrm{NHE}$ or PNHE, $37^{\circ} \mathrm{C}, 5$ minutes.

$\mathrm{C}^{\prime} 3 \mathrm{a}$ is not shared by other red cell populations containing a high proportion of reticulocytes and is not attributable to a special affinity of young red cells for $\mathrm{C}^{\prime} 3 \mathrm{a}$.

Immunoelectrophoresis of rechromatographed $C^{\prime} 3 a$. Two precipitin bands were identifiable by

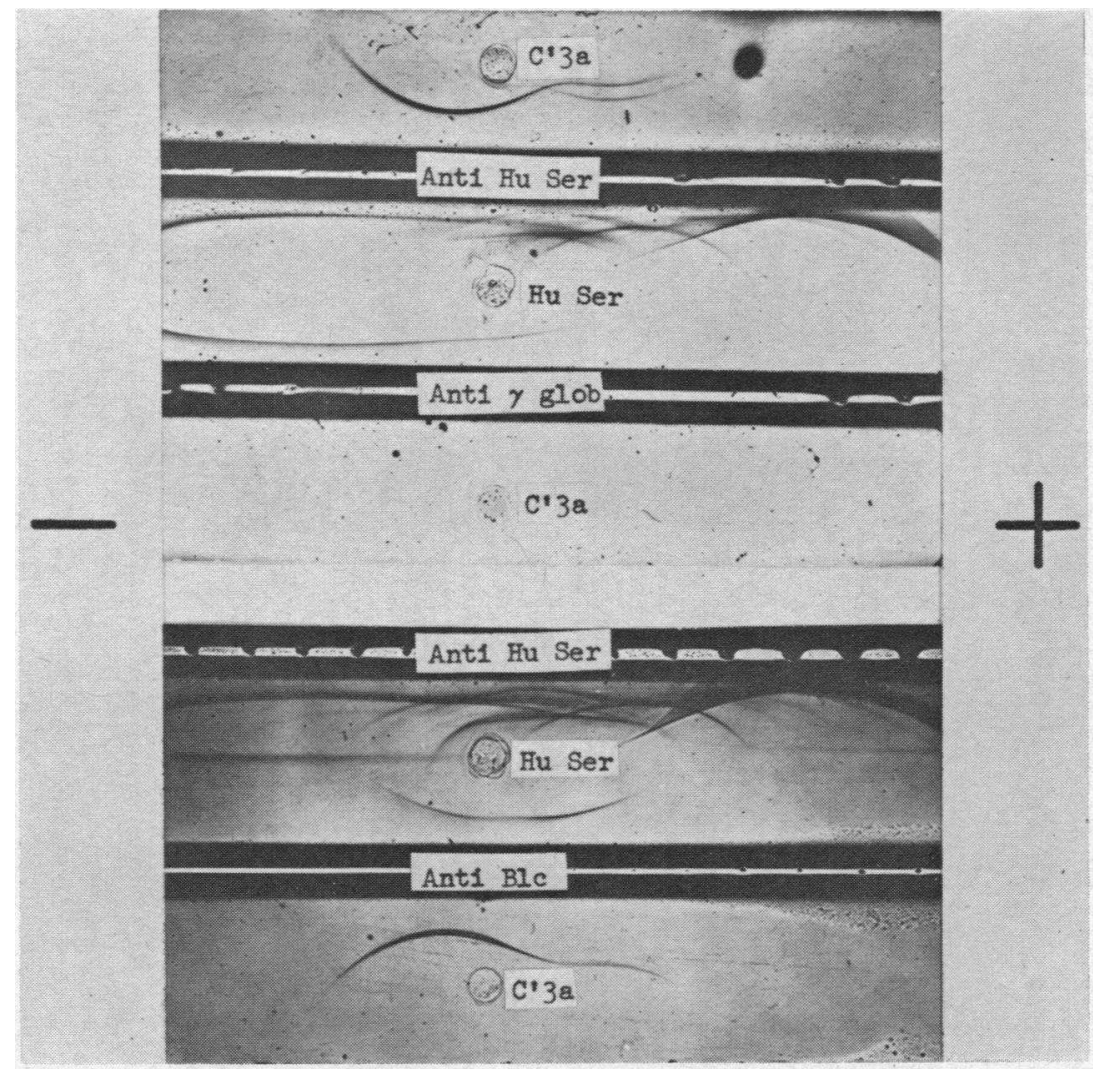

Fig. 8. Immunoelectrophoresis OF ReChromatographed C'3a. Antihuman serum:antiserum to whole human serum; anti- $\gamma$-globulin:antiserum to human $\gamma$-globulin; anti- $\beta_{1 \mathrm{Ic}}$ : antiserum to $\beta_{1 \mathrm{c}}$-globulin. 
STANLEY YACHNIN

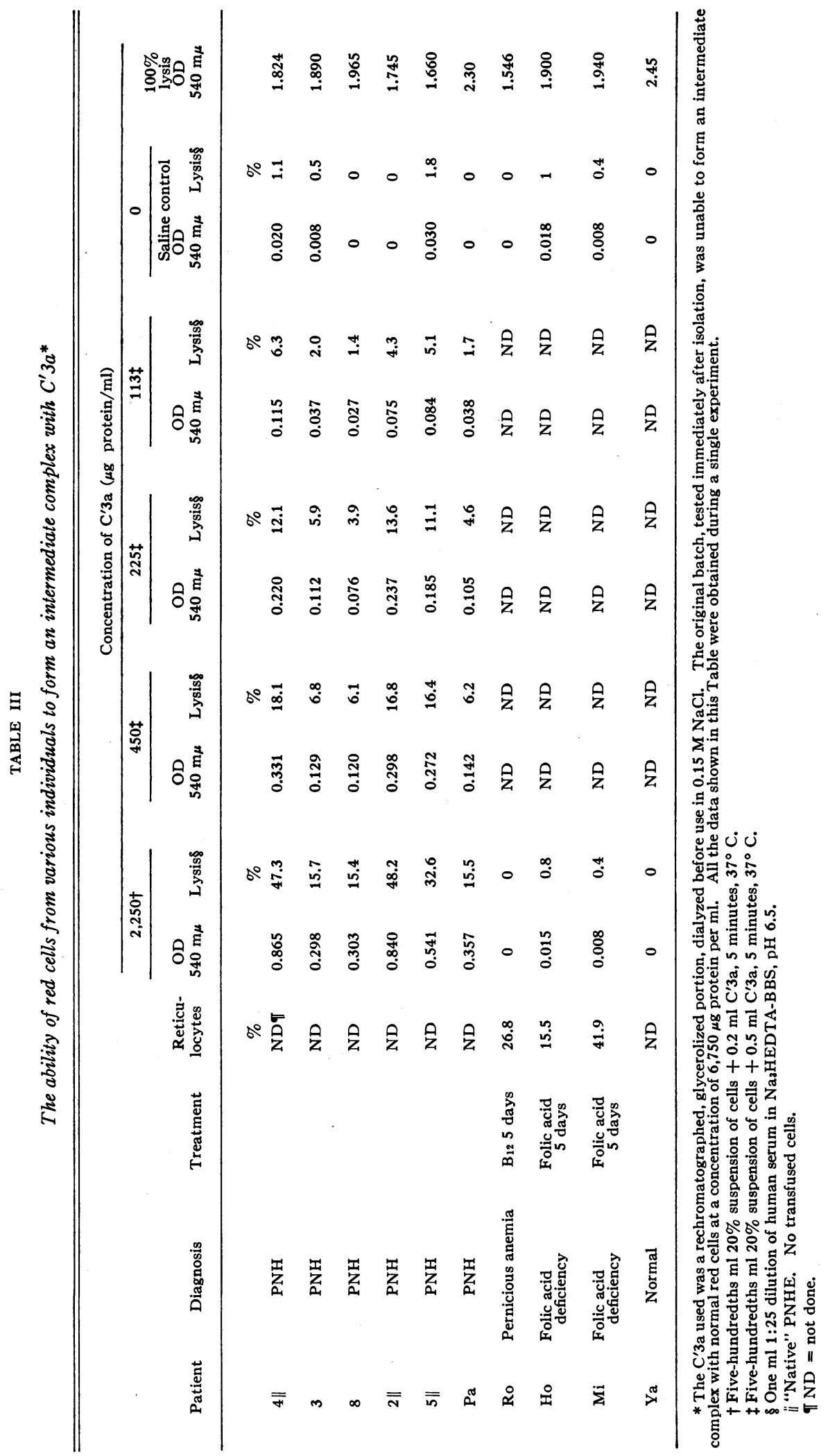


TABLE IV

Hemagglutination pattern of human red cells exposed to $C^{\prime} 3 a$ when tested with a rabbit antihuman serum*

\begin{tabular}{|c|c|c|c|c|c|c|c|c|}
\hline \multirow[b]{2}{*}{ Cell type } & \multirow[b]{2}{*}{ Antiserum } & \multicolumn{7}{|c|}{ Antiserum dilution } \\
\hline & & $1: 10$ & $1: 20$ & $1: 40$ & $1: 80$ & $1: 160$ & $1: 320$ & $\begin{array}{l}\text { Saline } \\
\text { control }\end{array}$ \\
\hline PNHE & Antihuman serum & 0 & 0 & 0 & $1+$ & 0 & 0 & 0 \\
\hline NHE & Antihuman serum & 0 & 0 & 0 & 0 & 0 & 0 & 0 \\
\hline $\begin{array}{l}\text { PNHE exposed } \\
\text { to } \mathrm{C}^{\prime} 3 \mathrm{a}\end{array}$ & Antihuman serum & $4+$ & $4+$ & $3+$ & $2+$ & $1+$ & \pm & 0 \\
\hline $\begin{array}{l}\text { NHE exposed } \\
\text { to } C^{\prime} 3 a\end{array}$ & Antihuman serum & $4+$ & $3+$ & $2+$ & \pm & 0 & 0 & 0 \\
\hline $\begin{array}{l}\text { PNHE exposed } \\
\text { to } C^{\prime} 3 \mathrm{a}\end{array}$ & $\begin{array}{l}\text { Antihuman serum } \\
\text { absorbed with } C^{\prime} 3 a\end{array}$ & 0 & 0 & 0 & 0 & 0 & 0 & 0 \\
\hline $\begin{array}{l}\text { NHE exposed } \\
\text { to } C^{\prime} 3 a\end{array}$ & $\begin{array}{l}\text { Antihuman serum } \\
\text { absorbed with } C^{\prime} 3 a\end{array}$ & 0 & 0 & 0 & 0 & 0 & 0 & 0 \\
\hline
\end{tabular}

* PNHE and NHE exposed to $C^{\prime} 3 a$ gave negative patterns when tested with anti- $\gamma$-globulin serum and anti- $\beta_{10}$ globulin serum. See Methods for details of procedure.

immunoelectrophoresis. One of them, $\beta_{1 \mathrm{c}}$-globulin, showed a minor component with greater anodal electrophoretic mobility. The other band detected by rabbit antihuman serum was not further identified. No $7 \mathrm{~S} \gamma$-globulin was present in the $\mathrm{C}^{\prime} 3 \mathrm{a}$ preparations (Figure 8).

Coombs tests. After exposure to $\mathrm{C}^{\prime} 3 \mathrm{a}$ both $\mathrm{PNHE}$ and NHE gave a positive hemagglutination reaction with antihuman serum; cells similarly treated did not react with anti- $\beta_{1 \mathrm{c}}$-globulin or anti-7 $\mathrm{S} \gamma$-globulin. Preabsorption of the antihuman serum with $\mathrm{C}^{\prime} 3 \mathrm{a}$ abolished the positive hemagglutination reaction (Table IV).

\section{Discussion}

Although much has been learned about the mechanism of $\mathrm{C}^{\prime}$ action during the preceding decade (14), the precise nature of the damage inflicted upon the red cell membrane that leads to subsequent lysis is not known, nor is it known which of the several $\mathrm{C}^{\prime}$ components acts to produce the ultimate membrane injury. Certain $C^{\prime}$ components presumably function only to activate later-acting $\mathrm{C}^{\prime}$ components necessary for the development of progressive stages in immune lysis. Since the $C^{\prime}$ components involved in such function need not be present on the cell membrane when lysis actually occurs, these $\mathrm{C}^{\prime}$ components are probably not involved in membrane injury. $\mathrm{C}^{\prime} 1$, for example, is dispensable after the attachment of $\mathrm{C}^{\prime} 4$ and $\mathrm{C}^{\prime} 2$, and cells in the state $\mathrm{EAC}_{4,2}^{\prime}$ can be readily lysed by $C^{\prime} 3$ (12). In an analogous fashion $C^{\prime} 2$ is only necessary for the attachment of $C^{\prime} 3 \mathrm{a}$; cells in the state $\mathrm{EAC}_{\mathbf{1}, \mathbf{4}, \mathbf{3 a}}^{\prime}$ (or presumably $\mathrm{EAC}_{\mathbf{4}, \mathbf{3 a}}^{\prime}$ ) need only be exposed to $C^{\prime} 3 b$ and $C^{\prime} 3 c$ for lysis to occur (15). ${ }^{7}$ Since no method is yet known of removing or inactivating cell bound $\mathrm{C}^{\prime} 4$, the possibility that it plays a role in the terminal phases of immune lysis cannot be excluded with certainty. It is, however, equally possible that $\mathrm{C}^{\prime} 4$ is not required beyond the activation and attachment of $\mathrm{C}^{\prime} 2$ and that cells in the state $\mathrm{EAC}_{3 \mathrm{a}}$ would hemolyze in the presence of $C^{\prime} 3 b$ and $C^{\prime} 3 c$. Such a possibility is suggested by the experiments described in this paper.

The ability of PNHE to combine directly with partially purified $\mathrm{C}^{\prime} 3 \mathrm{a}$ and to form an intermediate complex susceptible to lysis by $\mathrm{C}^{\prime} 3 \mathrm{~b}$ and $\mathrm{C}^{\prime} 3 \mathrm{c}$ confirms the observations of Rosen made with radioiodinated C'3a (16) and substantiates our earlier speculations that PNHE might be susceptible to lysis by late-acting complement components attaching directly from the fluid phase (4). Taken together with the findings of Jenkins that PNHE remaining intact after acid hemolysis in whole serum bear on their surface $C^{\prime} 3 a$, but not $C^{\prime} 4$ (17), the present observations permit us to make certain

${ }^{7}$ Linscott and Nishioka (15) have identified four subcomponents of guinea pig $\mathrm{C}^{\prime} 3$ and have called them $\mathrm{C}^{\prime} 3 \mathrm{a}$, $\mathrm{C}^{\prime} 3 \mathrm{~b}, \mathrm{C}^{\prime} 3 \mathrm{c}$, and $\mathrm{C}^{\prime} 3 \mathrm{~d}$. Although definitive data on the relationship between the human $\mathrm{C}^{\prime} 3$ subcomponents described in this report and guinea pig $C^{\prime} 3$ subcomponents are not presently available, for the purpose of discussion the following have been assumed: hu $C^{\prime} 3 a \approx g p C^{\prime} 3 c+$ gp $C^{\prime} 3 b ;$ hu $C^{\prime} 3 b \approx g p C^{\prime} 3 a ; h u C^{\prime} 3 c \approx g p C^{\prime} 3 d$. 
approximate statements about the mechanism of PNHE lysis by acidified whole human serum in vitro. There remains little reason to doubt that in vitro lysis of $\mathrm{PNHE}$ is effected by the $\mathrm{C}^{\prime}$ system, and not by any esoteric species of serum factors, inhibitors, or activators (18). In this respect, PNHE lysis does not differ from classical immune hemolysis. A striking difference between these two $C^{\prime}$-dependent hemolytic systems does exist, however, in the localization of the earlier stages of the $C^{\prime}$ sequence. In the case of immune lysis these early stages, mediated by the antibody coat, occur in apposition to the cell membrane; in PNHE lysis they take place in the fluid phase. The susceptibility of the PNHE hemolytic system to dilution implies that the fluid phase activation steps involved are not very efficient, and the lack of significant $\mathrm{C}^{\prime}$ consumption during $\mathrm{PNHE}$ lysis confirms this impression (19). In addition, PNHE, lacking a $\mathrm{C}^{\prime}$-activating mechanism (antibody coat), are deprived of the ability to exert any direct influence on the initiation and localization of $\mathrm{C}^{\prime}$ action $(4,20)$. The need for participation of fluid phase early $\mathrm{C}^{\prime}$ components in PNHE lysis in acid serum is attested to by the dependence of acid hemolysis on $\mathrm{Mg}^{++}(2)$, implying that at least $\mathrm{C}^{\prime} 2$ is involved in fluid phase events. Taken in the framework of our current knowledge of the role of $\mathrm{C}^{\prime} 2$ in $\mathrm{C}^{\prime}$-dependent lysis, it seems reasonable to conclude that these $\mathrm{C}^{\prime} 2$-mediated fluid phase events are preceded by action of $C^{\prime} 1$ (21) (and possibly $\mathrm{C}^{\prime} 4$ ) and that they are concerned with rendering $\mathrm{C}^{\prime} 3$ a capable of attachment (possibly by activation) to $\operatorname{PNHE}(4,22,23)$. One can "drive" the entire sequence of early phase events and increase resultant PNHE lysis by adding to the system $\mathrm{C}^{\prime} 1$ activators, $C^{\prime} 1 \mathrm{a}$, or $\mathrm{C}^{\prime} 1$ esterase (4). That a delicate balance exists in this fluid phase mechanism is shown by the inhibition of PNHE lysis by an excess of these "driving" materials (4). This inhibition is probably due to inactivation of $\mathrm{C}^{\prime} 2$ (possibly $\mathrm{C}^{\prime} 4$ ) or $\mathrm{C}^{\prime} 3 \mathrm{a}$ or both. Bypassing the early fluid phase events concerned with $\mathrm{C}^{\prime} 3 \mathrm{a}$ activation, and placing $\mathrm{C}^{\prime} 3 \mathrm{a}$ directly on PNHE, erases all distinction between the $\mathrm{PNHEC}_{3 \mathrm{a}}$ complex and its counterpart in immune hemolysis, $\mathrm{EAC}^{\prime}{ }_{1,4,2,3 \mathrm{a}}$. Both cells are now susceptible to lysis in the absence of $\mathrm{Ca}^{++}$or $\mathrm{Mg}^{++}$, both can be hemolyzed by high dilutions of human serum, both will hemolyze in R1, R2, and R4 but not R3 (1), and both can be attacked directly and hemolyzed by purified $C^{\prime} 3 b$ and $C^{\prime} 3 c(1)$. Although all of these statements can be made with some degree of certainty in terms of in vitro PNHE lysis, their exact relationship to in vivo PNHE hemolysis remains less clear. It does not, however, seem unreasonable to assume that the $\mathrm{C}^{\prime}$ system plays a similar role in intravascular PNHE destruction. Recognition of this fact may help in the search for effective ways of controlling the rate of red cell destruction in vivo.

Müller-Eberhard and Nilsson have shown that serum exposed to zymosan at $15^{\circ} \mathrm{C}$ suffers conversion of its $\beta_{1 \mathrm{c}}$-globulin to $\beta_{1 \mathrm{a}}$-globulin, a hemolytically inert component $(7)$. Such serum treatment is the method by which RP serum is ordinarily prepared (24). We have previously demonstrated that RP serum can be made to hemolyze PNHE by the addition of a potent $C^{\prime} 1$ activator (4). The present report demonstrates that $\mathrm{RP}$ serum is effective in hemolyzing PNHEC $_{3 \mathrm{a}}$. These observations, taken together, point to a close relationship between $\mathrm{C}^{\prime} 3 \mathrm{a}$ and properdin.

When subjected to immunoelectrophoretic analysis, our $C^{\prime} 3$ a preparations display at least two distinct protein fractions. One of them, $\beta_{1 \mathrm{c}}$-globulin, shows a minor subcomponent with greater anodal electrophoretic mobility; this could represent $\beta_{1 \mathrm{a}}$-globulin, an inactive fragment of $\beta_{1 \mathrm{c}^{-}}$ globulin formed by aging (6), or $\beta_{1 \mathrm{~g}}$-globulin, the reaction product of $C^{\prime} 2 \mathrm{a}$ and $\beta_{1 \mathrm{c}}$-globulin (22). The second constituent has not been identified but may be either $\beta_{1 \mathrm{f}^{-}}$globulin or $\mathrm{C}^{\prime} 6$, which have been shown by Nilsson and Müller-Eberhard to be present in $C^{\prime} 3 \mathrm{a}$ fractions prepared by their original method (23). The hemagglutination studies demonstrate the presence of a serum protein constituent on $\mathrm{PNHEC}_{3 \mathrm{a}}^{\prime}$ that is distinct from $\beta_{1 \mathrm{c}}$-globulin. Whether this serum protein fraction is $\beta_{1 \mathrm{r}}$-globulin, $C^{\prime} 6$, or both has not been ascertained.

We have previously cited evidence that eliminates the possibility that $\mathrm{PNHE}$ are in the state PNHEC $_{1,4,2}^{\prime}(4)$. Since the $C^{\prime} 3$ a utilized during the present studies contains at least two and probably three $\mathrm{C}^{\prime} 3$ a subcomponents (23), it might be argued that one of these activities is already attached to PNHE and effects the attachment of the others. However, the observations of Linscott and Nishioka (15) and of Nilsson and Müller-Eberhard (23) indicate that the components comprising 
$\mathrm{C}^{\prime} 3$ a activity require cell bound $\mathrm{C}^{\prime} 2 \mathrm{a}$ for attachment during immune lysis. The experiments utilizing decayed PNHE clearly demonstrate that cell bound $\mathrm{C}^{\prime} 2$ plays no direct role during the attachment of $\mathrm{C}^{\prime} 3 \mathrm{a}$. Although $\mathrm{PNHE}$ presumably go through a state equivalent to $\mathrm{PNHEC}_{3 \mathrm{a}}$ in vivo, such cells are probably destroyed by $\mathrm{C}^{\prime} 3 \mathrm{~b}$ and $\mathrm{C}^{\prime} 3 \mathrm{c}$ almost immediately, since PNHE studied in vitro are resistant to hemolysis in the absence of $\mathrm{Mg}^{++}$ (2).

Certain activators of $C^{\prime} 1$ such as polyinosinic acid and dextran sulfate are capable of initiating lysis of NHE as well as PNHE (4). The mechanism of induction of such hemolysis has been presumed to involve the same fluid phase $\mathrm{C}^{\prime}$ component events as those involved in PNHE hemolysis. Viewed in the light of these prior observations, it is not surprising to discover that $\mathrm{NHE}$ are also susceptible to direct attack by $\mathrm{C}^{\prime} 3 \mathrm{a}, \mathrm{C}^{\prime} 3 \mathrm{~b}$, and $\mathrm{C}^{\prime} 3 \mathrm{c}$, albeit to a far lesser extent than PNHE. The demonstration that both diseased and normal human red cells are capable, under proper conditions, of combining directly with $\mathrm{C}^{\prime} 3 \mathrm{a}$ without the direct mediation of an antibody coat or earlier cell bound $\mathrm{C}^{\prime}$ components suggests that human red cells bear on their surface receptor sites for such an attachment. The PNH red cell differs from NHE in having a greater number of such sites or in having them more accessible to fluid phase $C^{\prime} 3 \mathrm{a}$. Thus, whatever the nature or pathogenesis of the membrane lesion of PNHE (and it is clear that the present report throws little light on this fundamental question), we can at least say that it increases the affinity of the PNHE membrane for $\mathrm{C}^{\prime} 3 \mathrm{a}$ when compared with the normal human red cell membrane, and that this affinity makes PNHE susceptible to attack by fluid phase processes of $\mathrm{C}^{\prime}$ activation ordinarily insufficient to attack NHE. If the biochemical nature of the membrane site involved in $\mathrm{C}^{\prime} 3 \mathrm{a}$ attachment were established, it might provide an avenue through which more definitive understanding of the nature of the membrane lesion in PNH could be obtained.

\section{Summary}

Partially purified preparations of a sulscomponent of the third component of complement $\left(C^{\prime} 3 a\right)$ are capable of attaching directly to red cells of patients with paroxysmal nocturnal hemoglobinuria (PNHE). The intermediate complex thus formed
$\left(\mathrm{PNHEC}_{3 \mathbf{a}}^{\prime}\right.$ ), in contradistinction to $\mathrm{PNHE}$, is susceptible to hemolysis by high dilutions of human serum in the absence of $\mathrm{Ca}^{++}$or $\mathrm{Mg}^{++}$. $\mathrm{PNHEC}_{3 \mathrm{a}}$ will hemolyze in serum lacking properdin, or the first, second, or fourth components of complement, but not in serum depleted of $\mathrm{C}^{\prime} 3$ by zymosan. Hemolysis of PNHEC $_{3 \mathrm{a}}$ can be effected by partially purified late-acting subcomponents of $\mathrm{C}^{\prime} 3$, and the behavior of $\mathrm{PNHEC}_{3 \mathrm{a}}$ in all respects resembles that of their counterpart in classical immune lysis, $\mathrm{EAC}^{\prime}{ }_{1,4,2,3 \mathrm{a}}$. Normal human red cells are also susceptible to hemolysis by partially purified subcomponents of $C^{\prime} 3$, but to a much lesser extent than PNHE. These findings confirm earlier speculation that in ordinary acid hemolysis in whole human serum, early fluid phase events in $C^{\prime}$ activation lead to direct attack of $\mathrm{PNHE}$ by $\mathrm{C}^{\prime} 3$, without the mediation of cell bound complement components. The difference between normal human red cells and PNHE would appear to be a difference involving the number of accessibility of membrane sites concerned with the attachment of $\mathrm{C}^{\prime} 3 \mathrm{a}$.

\section{Acknowledgments}

These studies would not have been possible without the continuing cooperation of Dr. Frank H. Gardner, Peter Bent Brigham Hospital, Boston, Mass., and Drs. Robert C. Hartmann and David E. Jenkins, Jr., Hematology Service, Vanderbilt University School of Medi-ine, Nashville, Tenn., in supplying us with $\mathrm{PNH}$ red cells over a period of many months. Three patients from the Boston area and six patients from Tennessee were studied. We are also grateful to Drs. Nicolas Costea and Paul Heller, Veterans Administration West Side Hospital, Chicago, Ill., for allowing us to study one case of $\mathrm{PNH}$ under their care. Dr. Stephen Schwartz, Director of Hematology, Hektoen Institute, Cook County Hospital, Chicago, Ill., was kind enough to supply us with blood from two patients recovering from folic acid deficiency. Mrs. Janet M. Ruthenberg ably participated in many of the experiments cited. The initial isolations of $C^{\prime} 3$ a were performed by Mr. Satish Gupta.

\section{References}

1. Taylor, A. B., and M. A. Leon. Isolation of three components of the C'3 complex. Fed. Proc. 1961, 20, 19.

2. Yachnin, S., and J. M. Ruthenberg. The role of calcium in complement dependent hemolysis. Proc. Soc. exp. Biol. (N. Y.) 1964, 117, 179.

3. Yachnin, S., and J. M. Ruthenberg. pH optima in immune hemolysis: a comparison between guinea pig and human complement. J. clin. Invest. 1965, 44, 149. 
4. Yachnin, S., and J. M. Ruthenberg. The initiation and enhancement of human red cell lysis by activators of the first component of complement and by first component esterase; studies using normal red cells and red cells from patients with paroxysmal nocturnal hemoglobinuria. J. clin. Invest. 1965, 44, 518.

5. Lepow, I. H., G. B. Naff, E. W. Todd, J. Pensky, and C. F. Hinz, Jr. Chromatographic resolution of the first component of human complement into three activities. J. exp. Med. 1963, 117, 983.

6. Müller-Eberhard, H. J., U. Nilsson, and T. Aronsson. Isolation and characterization of two $\beta_{1}$-glycoproteins of human serum. J. exp. Med. 1960, 111, 201.

7. Müller-Eberhard, H. J., and U. Nilsson. Relation of a $\beta_{1}$-glycoprotein of human serum to the complement system. J. exp. Med. 1960, 111, 217.

8. Peetom, F., K. W. Pondman, M. van der Hart, and J. J. van Loghem. Qualitative differences in the mechanism of complement fixation. Nature (Lond.) 1963, 197, 911.

9. Hewitt, B. R. Spectrophotometric determination of protein in alkaline solution. Nature (Lond.) 1958, 182, 246.

10. Kabat, E. A., and M. M. Mayer. Experimental Immunochemistry. Springfield, Ill., Charles C Thomas, 1961, p. 176 ; a) p. 181.

11. Mayer, M. M., L. Levine, H. J. Rapp, and A. A. Marucci. Kinetic studies on immune hemolysis. VII. Decay of $E A C_{1,4,2}^{\prime}$, fixation of $C^{\prime} 3$, and other factors influencing the hemolytic action of complement. J. Immunol. 1954, 73, 443.

12. Becker, E. L. Concerning the mechanism of complement action. V. The early steps in immune hemolysis. J. Immunol. 1960, 84, 299.

13. Leon, M. A. Quantitative studies on the properdincomplement system. II. Kinetics of the reaction between properdin and zymosan. J. exp. Med. 1957, 105, 403.

14. Austen, K. F., and Z. A. Cohn. Contribution of serum and cellular factors in host defense reactions. I. Serum factors in host resistance. New Engl. J. Med. 1963, 268, 933.

15. Linscott, W. D., and K. Nishioka. Components of guinea pig complement. II. Separation of serum fractions essential for immune hemolysis. J. exp. Med. 1963, 118, 795.

16. Rosen, F. Personal communication.

17. Jenkins, D. E., Jr. Personal communication.

18. Crosby, W. H. Paroxysmal nocturnal hemoglobinuria. Plasma factors of the hemolytic system. Blood 1953, 8, 444.

19. Hartmann, R. C., and D. E. Jenkins, Jr. Paroxysmal nocturnal hemoglobinuria: current concepts of certain pathophysiologic factors. Blood 1965, 25, 850.

20. Hinz, C. F., Jr., and A. M. Mollner. Studies on immune human hemolysis. III. Role of $11 \mathrm{~S}$ component initiating the Donath-Landsteiner reaction. J. Immunol. 1963, 91, 512.

21. Stroud, R. M., K. F. Austen, and M. M. Mayer. Immune hemolysis: kinetics of enzymatic activation and fixation of $\mathrm{C}^{\prime} 2$ by activated $\mathrm{C}^{\prime} 1$ ( $\left.\mathrm{C}^{\prime} 1 \mathrm{a}\right)$. Fed. Proc. 1963, 22, (suppl. 13), 613.

22. Müller-Eberhard, H. J., M. A. Calcott, and M. R. Mardiney. Conversion of $\beta_{1 \mathrm{c}}$-globulin by $\mathrm{C}^{\prime} 2 \mathrm{a}$. Fed. Proc. 1964, 23, 506.

23. Nilsson, U., and H. J. Müller-Eberhard. Isolation of $\beta_{1 F}-$ globulin and its characterization as a complement component. Fed. Proc. 1964, 23, 506.

24. Pillemer, L., L. Blum, I. H. Lepow, O. A. Ross, E. W. Todd, and A. C. Wardlaw. The properdin system and immunity. I. Demonstration and isolation of a new serum protein, properdin, and its role in immune phenomena. Science 1954, 120, 279. 